\title{
Bioethanol Production from Oil Palm Empty Fruit Bunches Using Saccharomyces cerevisiae Immobilized on Sodium Alginate Beads
}

\author{
Andri Cahyo Kumoro ${ }^{1 *}$, Astrilia Damayanti², Zuhriyan Ash Shiddieqy Bahlawan², Mira Melina², \\ Heti Puspawati²

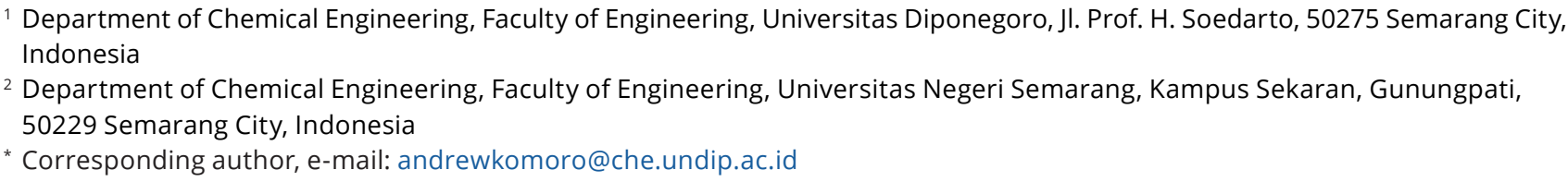

Received: 02 July 2020, Accepted: 16 November 2020, Published online: 12 July 2021

\begin{abstract}
Bioethanol is an environmentally benign renewable energy commonly obtained from glucose fermentation using Saccharomyces cerevisiae. The purposes of this study are to investigate the effects of time, temperature, $\mathrm{pH}$, immobilized yeast cell loading, beads reuse during ethanol production through batch fermentation of glucose derived from oil palm empty fruit bunches by $\mathrm{S}$. cerevisiae immobilized on $\mathrm{Na}$-alginate beads and to compare the performance of fermentation using immobilized yeast cells and that of using a free cell system. The results revealed that time, temperature, $\mathrm{pH}$, yeast mass and beads reuse significantly affected the ethanol and final glucose concentrations. As expected, a maximum ethanol concentration was obtained from fermentation using immobilized yeast cells at $30^{\circ} \mathrm{C}, \mathrm{pH} 5$, and immobilized yeast cell loading of $0.75 \mathrm{~g}$ for 48 hours. However, fermentation with a free cell system at the same conditions resulted in lower ethanol yield. The highest ethanol concentration of $88.125 \mathrm{~g} / \mathrm{L}$ with a productivity of $1.84 \mathrm{~g} / \mathrm{L} \cdot \mathrm{h}$ was achieved from the second cycle fermentation using of immobilized cells beads. The results suggest that an immobilized cell system exhibits great potential applications for improved ethanol production due to its ability to sustain the stability of cell activity, reduce contamination tendency, and protect yeast cells from any possible inhibitions.
\end{abstract}

\section{Keywords}

ethanol fermentation, glucose, Saccharomyces cerevisiae, immobilization, Na-alginate beads

\section{Introduction}

The steady increase of industrialization in entire parts of the world has caused a remarkable increase in fossil energy consumption by 2 to $3 \%$ per year, which finally fasten fossil fuel resource depletion [1]. One of the promising ways to overcome these problems is by substituting fossil energy with renewable energy resources, such as bioethanol from lignocellulosic biomass [2]. Furthermore, the use of bioethanol as alternative energy exhibits its superiority due to the fact that the combustion of bioethanol can reduce the greenhouse gas (GHG) e10missions by $34 \%$ [3].

Usually, commercial-scale bioethanol production from glucose employs an anaerobic fermentation process involving yeasts, which mainly Saccharomyces cerevisiae [4, 5], Saccharomyces bayanus [6], Saccharomyces pastorianus [7], and Kluyveromyces marxianus [8]. Glucose as a substrate for bioethanol preparation can be derived from agricultural waste such as oil palm empty fruit bunch (OPEFB) through enzymatic saccharification although this process requires a long reaction time of about 24 to 72 hours [9, 10]. Waluyo et al. [11] performed the enzymatic hydrolysis of alkaline pretreated OPEFB particles with $5 \mathrm{~mm}$ average diameter using the cocktail of Cellic ${ }^{\circledR} \mathrm{CTec} 2$ and Cellic ${ }^{\circledR} H$ Tec 2 enzymes $(5: 1)$ in batch mode at $50{ }^{\circ} \mathrm{C}$ for 72 hours to obtain glucose concentration of $63.83 \mathrm{~g} / \mathrm{L}$. Fedbatch enzymatic hydrolysis of alkaline and steam explosion pretreated OPEFB powder using Cellic CTec 2 for 120 hours could result in $172 \mathrm{~g} / \mathrm{L}$ of glucose concentration [12]. Chin et al. [13] studied the acid hydrolysis of alkaline and bleaching pretreated OPEFB using $5 \mathrm{~N}$ sulfuric acid at $139.5^{\circ} \mathrm{C}$ for 4.16 hours and $4.63 \mathrm{~N}$ hydrochloric acid at $133.7^{\circ} \mathrm{C}$ for 
2.05 hours to obtain respectively $30.61 \%$ and $39.81 \%$ total reducing sugar. Sumathi et al. [14] reported that the estimated value of world annual production of oil palm empty fruit bunch could reach approximately 37.7 million tons. As the world's leading crude oil palm producers, both Indonesia and Malaysia generate roughly 17 million tons of OPEFB every year from their crude palm oil extraction process [13]. In general, the OPEFB contains about 42.7 to $65 \%$ cellulose, 17.1 to $33.5 \%$ hemicellulose, 13.2 to $25.31 \%$ lignin and 1.30 to $6.04 \%$ ash [15], which offers large potential as a raw material for glucose preparation [16].

Batch fermentation of glucose offers easy operation and control with low investment costs to obtain high bioethanol yield [17]. The main influential factors that affect the bioethanol production from glucose fermentation are time [18], temperature, $\mathrm{pH}[19,20]$, and inoculum concentration [21]. Basically, both Saccharomyces cerevisiae as the mesophilic and $K$. marxianus as the thermotolerant yeasts are acidophilic microorganisms. Therefore, they would prefer to grow under acidic rather than basic fermentation environment. The optimum $\mathrm{pH}$ range for yeast to grow can be different from 4.0 to 6.0 , which largely depends on the temperature, existence of oxygen, and strain of yeast [22]. Waluyo et al. [11] studied bioethanol production by fermentation of glucose with initial glucose concentration of $63.83 \mathrm{~g} / \mathrm{L}$ at $32{ }^{\circ} \mathrm{C}$ and $\mathrm{pH} 4.8$ for 92 hours using free and immobilized $S$. cerevisiae cells on Ca-alginate beads and reported that the highest ethanol concentrations obtained were $29.44 \mathrm{~g} / \mathrm{L}$ and $29.76 \mathrm{~g} / \mathrm{L}$, respectively. The optimum conditions for glucose fermentation using $S$. cerevisiae to achieve maximum ethanol production were at 25 to $40{ }^{\circ} \mathrm{C}[23,24], \mathrm{pH} 5[17,25]$, and inoculum concentration of $1 \times 10^{8}$ cells $/ \mathrm{mL}$ for 48 hours [26, 27]. Fermentation techniques using immobilized yeast cells produced higher ethanol concentrations than free cells [28, 29] because the immobilized cells possess restricted movement spaces [30]. Cell immobilization in certain bead particles provides interesting benefits, which include easy separation of yeast cells from the medium, a considerable cost reduction due to cell reuse in subsequent fermentation cycles, and a lower tendency of contamination [31].

The simplest immobilization technique used for the entrapment of yeast cells is by extrusion dripping [32]. The Na-alginate isolated from seaweed or brown algae is the most used immobilization matrix due to its strong ability to form round beads with high cell density [28, 33]. A higher concentration of Na-alginate matrix has been reported to adsorb a higher density of yeast cells [28]. The optimum concentration of Na-alginate in bioethanol production from discarded carrot is $2 \%(\mathrm{w} / \mathrm{v})$, which produces uniform beads with a strong mechanical structure [34].

To the extent of our knowledge, most of the previous publications reported the production of bioethanol through fermentation of substrate containing reducing sugar originated from fruit and sweet sorghum juice wastes, starch hydrolysate and refined glucose using free yeast cells or yeast cells immobilized on calcium-alginate beads [11] and/or various cellulose based porous matrices. Although numerus research groups have carried out ethanol production studies through fermentation using immobilized yeast; however, low beads reusability, productivity and mechanical strength have been reported as the main weaknesses. There is also a lack of information on the direct fermentation of substrate made of crude glucose derived from OPEFB into bioethanol using $S$. cerevisiae immobilized on Na-alginate beads. Therefore, the aims of this study are to investigate the best conditions for fermentation of crude glucose derived from OPEFB by $S$. cerevisiae immobilized on Na-alginate beads, to compare the performance of fermentation using immobilized and free cell system and to investigate the effect of beads reuse by observing the stability and activity of microorganisms attached on the beads to obtain a more efficient process with low production cost.

\section{Materials and methods}

\subsection{Source of OPEFB, yeast and enzymes}

The OPEFB used in this work was a kind donation from PT. Perkebunan Nusantara VII, Lampung Tengah, Indonesia. Whereas the $S$. cerevisiae was obtained from Instant Dry Yeast ("Fermipan", Indonesia). The amount of yeast mass used was $0.5183 \mathrm{~g}$ with a cell density of $1 \times 10^{8}$ cells/mL [26]. The number of yeast cell was quantified by the haemocytometer cell counting method [35]. Celluclast 1.5 L (Cellulase) and Novozyme 188 (Cellobiase) were purchased from Novozymes Malaysia Sdn. Bhd.

\subsection{Chemicals}

Crude glucose was obtained from enzymatic hydrolysis of cellulose extracted from autohydrolysis delignified oil palm empty fruit bunches using a cocktail enzyme comprised of equal amount of Celluclast $1.5 \mathrm{~L}$ and Novozyme 188 as suggested by Pasma et al. [36]. The crude glucose was further concentrated in a vacuum evaporator at $50{ }^{\circ} \mathrm{C}$ for 30 minutes to obtain glucose concentration of $172 \mathrm{~g} / \mathrm{L}$. The chemicals utilized in this study were all of analytical grade with minimum purity of $99.8 \% \mathrm{w} / \mathrm{w}$. They were the product of Sigma Aldrich and were purchased from $\mathrm{CV}$. 
Chem-Mix Pratama, Yogyakarta - Indonesia. All of the chemicals were directly used without pre-treatment.

\subsection{Cells suspension}

A $50 \mathrm{~mL}$ growing medium containing $5 \mathrm{~g} / \mathrm{L}$ peptone and 10 $\mathrm{g} / \mathrm{L}$ crude glucose obtained from enzymatic hydrolysis of oil palm fruit bunch was prepared in a $250 \mathrm{~mL}$ Erlenmeyer flask. The mixture was then sterilized using an autoclave at $121{ }^{\circ} \mathrm{C}$ for 15 minutes and it was further equilibrated to room temperature [31]. Upon the achievement of room temperature $\left(30^{\circ} \mathrm{C}\right)$, a carefully weighed $(0.50 \mathrm{~g}) \mathrm{S}$. cerevisiae instant dry yeast was added to the sterile cultivation medium. Furthermore, this sterile solution was introduced to an orbital shaker and let the shaker to operate at $150 \mathrm{rpm}$ under aseptic conditions for 24 hours at ambient temperature $\left(30{ }^{\circ} \mathrm{C}\right)$ to prevent or minimize the contamination by undesirable microbes in the early stage of growth of the yeast. After 24 hours aseptic mixing, the cell suspension was suspended in $100 \mathrm{~mL}$ sterile water and was ready for use [37].

\subsection{Immobilization of yeast cells}

One-gram Na-alginate (Sigma Aldrich) was dissolved in 50 $\mathrm{mL}$ distilled water to obtain a concentration of $2 \%(\mathrm{w} / \mathrm{v})$ and mixed with cell suspension in a ratio of $1: 1(\mathrm{w} / \mathrm{v})$ using a centrifuge at $4000 \mathrm{rpm}$ for $30 \mathrm{~s}$ to obtain high concentrations of yeast cells in a small volume [25]. Then, the solution of yeast cells and Na-alginate mixture was discharged into a $0.1 \mathrm{M} \mathrm{CaCl}_{2}$ solution at $30{ }^{\circ} \mathrm{C}$ through a syringe needle with the assistance of a syringe pump, which was operated at maximum capacity and delivered the solution at $0.25 \mathrm{~mL} /$ minute. Since the syringe needle diameter was very small $(3.5 \mathrm{~mm})$, a syringe adapter was placed between the syringe and syringe needle so that they were perfectly connected. The Na-alginate solution containing the yeast cells was discharged at the tip of the needle in the form of droplets $[37,38]$. The spherical $\mathrm{Na}$-alginate beads were allowed to solidify in $\mathrm{CaCl}_{2}$ solution as a result of ionic reaction between calcium and alginate under gentle agitation for 30 minutes using a magnetic stirrer [39]. The formed beads were then stored in a $\mathrm{CaCl}_{2}$ solution for $16-20$ hours at $4{ }^{\circ} \mathrm{C}$ [25]. The beads were filtered and washed with distilled water twice before being used for the fermentation process [31].

\subsection{Batch fermentation}

\subsubsection{Cellulose extraction from OPEFB}

Prior to cellulose extraction, the autohydrolysis pretreatment was carried out to the delignify the OPEFB.
A carefully weighed 50 grams of OPEFB dried powder $( \pm 1 \mathrm{~mm})$ was added into $500 \mathrm{~mL}$ deionized water in a $2 \mathrm{~L}$ stainless steel reactor. The autohydrolysis was performed at $101.33 \mathrm{kPa}$ and $120{ }^{\circ} \mathrm{C}$ with continuous stirring for 2 hours. As the reaction finished, the reactor was cooled to room temperature, the solid residue was recovered by filtration and dried in an electric oven at $105^{\circ} \mathrm{C}$ for overnight. Then, the oven dried - auto hydrolyzed OPEFB was milled $( \pm 200 \mu \mathrm{m})$ and mixed with $500 \mathrm{~mL}$ of $80 \% \mathrm{v} / \mathrm{v}$ aqueous ethanol and $0.2 \% \mathrm{w} / \mathrm{w}$ (based on the dried biomass) sulfuric acid as catalyst. The suspension was heated at $101.33 \mathrm{kPa}$ and $120^{\circ} \mathrm{C}$ for 1 hour, filtered and washed with methanol [40]. The solid residue was further treated by heating it in $500 \mathrm{~mL}$ of $2 \% \mathrm{v} / \mathrm{v}$ hydrogen peroxide solution at $101.33 \mathrm{kPa}$ and $50^{\circ} \mathrm{C}$ for 4 hours to obtain cellulose.

\subsubsection{Enzymatic hydrolysis of cellulose to obtain crude glucose}

Enzymatic hydrolysis experiment was carried out in $100 \mathrm{~mL}$ Erlenmeyer flask at $40^{\circ} \mathrm{C}$ and $145 \mathrm{rpm}$ in an incubator shaker. A thoroughly weighed $1.0 \mathrm{~g}$ of cellulose was added to $9 \mathrm{~mL}$ sodium acetate buffer ( $50 \mathrm{mM}, \mathrm{pH} 4.7)$ and incubated for 2 hours $\left(40{ }^{\circ} \mathrm{C}\right.$ and $\left.145 \mathrm{rpm}\right)$. After this preincubation step, hydrolysis was initiated by adding $8 \mathrm{~mL}$ of $10 \mathrm{mg} / \mathrm{mL}$ total enzyme cocktail (a mixture of novozyme 188 and celluclast with volume ratio of $1: 1$ ) (activity: $700 \mathrm{EGU/g}$ ). The enzymatic reaction was terminated by immediately incubating the sample in a hot water bath at $90{ }^{\circ} \mathrm{C}$ for 20 min to deactivate the enzyme [41]. Reaction was carried out at $40^{\circ} \mathrm{C}$, for 94 hours to yield glucose with $168 \mathrm{~g} / \mathrm{mL}$ concentration.

\subsubsection{Batch fermentation of crude glucose}

The fermentation medium used for the preparation of ethanol using both immobilized cells and free cells consists of nutrients $(2.5 \mathrm{~g} / \mathrm{L}$ yeast extract; yeast nitrogen base $1.7 \mathrm{~g} / \mathrm{L}$; $5 \mathrm{~g} / \mathrm{L}$ ammonium sulfate; $6 \mathrm{~g} / \mathrm{L}$ magnesium sulfate) and glucose as a substrate with a concentration of $172 \mathrm{~g} / \mathrm{L}$ [25]. The $\mathrm{pH}$ of the fermentation medium was regulated to $\mathrm{pH}$ 5.0 by the addition of $1 \mathrm{M} \mathrm{HCl}$ and $1 \mathrm{M} \mathrm{KOH}$. Prior to fermentation experiments, the fermentation medium was sterilized by autoclaving it at $121^{\circ} \mathrm{C}$ and $15 \mathrm{lb}$ pressure for 20 min. Batch fermentation was carried out in a $100 \mathrm{~mL}$ fermenter with a working volume of $50 \mathrm{~mL}$ at $30^{\circ} \mathrm{C}$. A predetermined $30 \%(\mathrm{w} / \mathrm{v})$ alginate beads were introduced into the fermentation medium in the fermenter.

This experiment was carried out with variations of fermentation time (24, 48, 72 , and 96 hours), temperature (25, $\left.30,35,40{ }^{\circ} \mathrm{C}\right), \mathrm{pH}(3,4,5$, and 6$)$, and immobilized yeast 
cell loading $(0.250 .5,0.75$ and $1 \mathrm{~g})$ to determine the optimum conditions of fermentation in the immobilized cell system. At the end of the fermentation, the sample was filtered and centrifuged at a speed of $2000 \mathrm{rpm}$ for $20 \mathrm{~min}-$ utes and the supernatant was subjected to ethanol and final glucose concentration analysis [25]. After 8 hours of fermentation, the Na-alginate beads were filtered from the fermentation broth and were reused for the second fermentation stage using a fresh fermentation medium containing the same amount of yeast mass of $0.75 \mathrm{~g}$. The fermentation was also performed at $30{ }^{\circ} \mathrm{C}$ and $\mathrm{pH} 5$ for 48 hours with liquid samples were withdrawn at 8 hours intervals. As a comparison, the fermentation of glucose using a free cell system was also conducted in this study. Cell suspension with a yeast mass of $0.75 \mathrm{~g}$ was added to the fermenter at $30 \%$ (w/v). Similar to the fermentation using an immobilized cell system, the fermentation free cell system was also performed at $30{ }^{\circ} \mathrm{C}$ and $\mathrm{pH} 5$ for 48 hours with liquid samples were withdrawn at 8 hours intervals.

\subsection{Analytical procedures}

\subsubsection{Glucose concentration}

Standard glucose solutions were prepared in concentrations of 2, 4, 6, 8 and $10 \mathrm{mg} / 100 \mathrm{~mL}$ in a $250 \mathrm{~mL}$ Erlenmeyer flask. A carefully measured $1 \mathrm{~mL}$ of Nelson reagent (A and $\mathrm{B}$ ) was added to $1 \mathrm{~mL}$ of standard glucose solutions of zero concentration (blank solution), 2, 4, 6, 8 and $10 \mathrm{mg} / 100 \mathrm{~mL}$. Then Erlenmeyer flask was hermetically closed, gently shaken until homogeneous, and then heated in a water bath heater at $100{ }^{\circ} \mathrm{C}$ for 15 minutes. The solution was equilibrated to ambient temperature before the addition of $1 \mathrm{~mL}$ of arsenomolybdate reagent. The solution was then let to stand for 1 minute to allow the precipitate to dissolve. After dilution of the blue solution with $50 \mathrm{~mL}$ distilled water, the absorbance was determined using a UV-Vis spectrophotometer at wave length of $540 \mathrm{~nm}$. A glucose concentration versus absorbance plot was drawn to acquire a linear correlation. The absorbance value of the sample was entered into this linear equation to obtain the glucose concentration of the sample $[42,43]$.

\subsubsection{Ethanol concentration}

The ethanol concentration in the fermentation broth was quantified according to the modified spectrophotometric method, which involves solvent extraction and dichromate oxidation reaction [44]. Anhydrous ethanol (Sigma
Aldrich) was dissolved in distilled water to obtain ethanol solution with concentrations ranged from 0.5 to $100 \mathrm{~g} / \mathrm{L}$. A carefully weighed $4.262 \mathrm{~g}$ of $\mathrm{K}_{2} \mathrm{Cr}_{2} \mathrm{O}_{7}$ (Sigma Aldrich) was dissolved with $100 \mathrm{~mL}$ distilled water in a $1000 \mathrm{~mL}$ volumetric flask. It was further added with $50 \mathrm{~mL}$ concentrated sulfuric acid solution and followed by a careful addition of distilled water to the scale of the volumetric flask. A carefully measured $1 \mathrm{~mL}$ of acidic dichromate solution was taken and diluted to $10 \mathrm{~mL}$ with distilled water. Approximately $5 \mathrm{~mL}$ of the dilute solutions was taken and introduced to the center of the conway cup. Meanwhile, the outside of the conway cup was filled with $5 \mathrm{~mL}$ of ethanol solution and $1 \mathrm{~mL}$ of $20 \% \mathrm{Na}_{2} \mathrm{CO}_{3}$ solution. The conway cup was covered and heated at $50{ }^{\circ} \mathrm{C}$ for 2 hours. The absorbance was measured using a UV-Vis spectrophotometer with a maximum wave length of $446 \mathrm{~nm}$ [45]. A calibration curve between the concentrations of the ethanol standard solution and their respective absorbance values was drawn to obtain a linear correlation.

In order to extract the ethanol from the fermentation broth sample, $1 \mathrm{~mL}$ of Tri-n-butyl phosphate (TBP) was vigorously vortexed with $1 \mathrm{~mL}$ of aqueous fermentation broth sample in a microtube for 1 minute. The mixture was then centrifuged at $3,420 \mathrm{~g}$ for $5 \mathrm{~min}$ to allow the separation of two phases. The upper phase was a clear and transparent TBP layer, while the lower phase was a turbid water layer. Then, $500 \mu \mathrm{L}$ of the upper phase was mixed with $500 \mu \mathrm{L}$ of dichromate reagent (containing $10 \% \mathrm{w} / \mathrm{v}$ of $\mathrm{K}_{2} \mathrm{Cr}_{2} \mathrm{O}_{7}$ in $5 \mathrm{M}$ of $\mathrm{H}_{2} \mathrm{SO}_{4}$ solution) in a new microtube, and vigorously vortexed for 1 minute. The mixture was let to stand for 10 minutes at $30{ }^{\circ} \mathrm{C}$ to allow the oxidation product in the lower phase developed blue green color. Prior to absorbance measurement using UV-Vis Spectrophotometer with a maximum wave length of $446 \mathrm{~nm}$, a carefully measured $100 \mu \mathrm{L}$ of the oxidation products were diluted with $900 \mu \mathrm{L}$ of deionized water. The ethanol concentration in the sample was calculated from the ethanol standard curve, which correlates the absorbance at $446 \mathrm{~nm}$ and the ethanol concentrations.

\subsubsection{Microstructure of the immobilized yeast cells}

Cell growth in alginate beads samples before and after 48 hours of fermentation was observed using a scanning electron microscope (SEM) (Phenom ProX desktop SEM with EDX). The alginate beads sample was cut into two parts to observe the inner (cross-sectional) surface. Samples were frozen for approximately 10 minutes before observation. 


\section{Results and discussion}

\subsection{Fermentation using immobilized yeast}

\subsubsection{Effect of time on the ethanol production}

In this study, the first stage of the experiment was performed at $\mathrm{pH} 5.0,30{ }^{\circ} \mathrm{C}$ and $0.50 \mathrm{~g}$ dry yeast to obtain the optimum fermentation time of the fermentation of glucose derived from oil palm empty fruit bunch using immobilized yeast cells, which resulted in the highest ethanol concentration. The ethanol concentration, ethanol productivity and final glucose concentration at various fermentation time are presented in Table 1.

Table 1 shows that the ethanol concentration increases with the increase of fermentation time and decreases in glucose concentration. The concentration of ethanol increased significantly by $79.86 \mathrm{~g} / \mathrm{L}$ in the first 16 hours, which was supposedly due to the speedy growth of yeast cells. Remarkable decrease of glucose concentration from $172.00 \mathrm{~g} / \mathrm{L}$ to $0.81 \mathrm{~g} / \mathrm{L}$ indicated that the yeast cells were alive, consumed glucose as the main substrate and grew rapidly and subsequently increased the immobilized cell activity. Based on their observation to the viable cells, da Silva et al. [46] found that yeast $S$. cerevisiae strain BB.09 showed resistance up to $8 \% \mathrm{v} / \mathrm{v}$ ethanol concentration, which is equivalent to $63.12 \mathrm{~g} / \mathrm{L}$ even when temperature was increased to $35{ }^{\circ} \mathrm{C}$. However, the alginate matrix gave protection to the entrapped yeast cells against ethanol stress and subsequently increased the number of survival immobilized cells as compared to free cells as reported by Norton and D'Amore [47]. The decline of glucose concentration during fermentation shows the effectiveness of yeast cells in consuming glucose as the main substrate [48]. This result is also consistent with those reported by previous research works [49, 50].

As expected, the ethanol concentration did not change significantly after 24 hours fermentation and the ethanol concentration remained constant beyond 48 hours of fermentation, which is most likely due to the depletion of glucose as substrate [51] or inhibition of yeast cells by ethanol or both. However, different phenomenon was observed by Waluyo et al. [11] as they reported that ethanol concentration gradually decreased after 48 hours fermentation of glucose using $S$. cerevisiae immobilized on Ca-alginate due to the evaporation of ethanol from the fermentation broth. Although the $\mathrm{pH}$ and temperature applied in the fermentation are closely similar, the use of higher initial glucose concentration, different source of $S$. cerevisiae and Na-alginate as the immobilizing media have resulted in a far higher value of the highest ethanol concentration achieved in this work than that was reported by Waluyo et al. [11]. Zhang et al. [52] observed that ethanol as the end product of the fermentation of glucose is the main factor that potentially inhibits the growth of yeast cells and reduces fermentation activity. As the exogenous ethanol concentration exceeded $84.84 \mathrm{~g} / \mathrm{L}$, the yeast cells completely stopped growing and fermenting the glucose. Further, they also reported that highly concentrated ethanol could inhibit the glucose mass transfer phenomenon and metabolic mechanism, and finally restricted the downstream metabolism route.

\subsubsection{Effect of temperature on the ethanol production}

The effect of temperature of fermentation was studied at $25^{\circ} \mathrm{C}, 30^{\circ} \mathrm{C}, 35^{\circ} \mathrm{C}$ and $40^{\circ} \mathrm{C}$ using $0.50 \mathrm{~g}$ dry yeast, while the $\mathrm{pH}$ was maintained at 5.0. Refer to the result obtained in the study of the effect of fermentation time, the fermentation process for the effect of temperature was performed up to 48 hours with sample withdrawal was set at 8 hours interval. The effect of fermentation temperature on ethanol and glucose concentrations is depicted in Fig. 1.

As intended, the growth of the yeast cells changed at different temperatures. The common microorganism growth curve involving a sequence of short-lag, exponential,

Table 1 Effect of time on fermentation parameters

\begin{tabular}{lcccc}
\hline Time (h) & Glucose Conc. $(\mathrm{g} / \mathbf{L})$ & Ethanol Conc. $(\mathrm{g} / \mathbf{L})$ & Ethanol Prod. $(\mathbf{g} / \mathbf{L} \cdot \mathbf{h})$ & Yield $(\%)$ \\
\hline 0 & $172.00 \pm 0.10$ & $0 \pm 0.00$ & $0 \pm 0.00$ & $0 \pm 0.00$ \\
8 & $27.30 \pm 0.08$ & $65.30 \pm 0.04$ & $8.40 \pm 0.02$ & $91.02 \pm 0.05$ \\
16 & $0.81 \pm 0.08$ & $79.86 \pm 0.10$ & $4.99 \pm 0.05$ & $91.29 \pm 0.12$ \\
24 & $0.72 \pm 0.02$ & $81.33 \pm 0.10$ & $3.39 \pm 0.05$ & $92.93 \pm 0.50$ \\
32 & $0.61 \pm 0.02$ & $82.50 \pm 0.05$ & $2.56 \pm 0.02$ & $94.19 \pm 0.03$ \\
40 & $0.45 \pm 0.03$ & $83.67 \pm 0.03$ & $2.09 \pm 0.03$ & $94.45 \pm 0.01$ \\
48 & $0.27 \pm 0.05$ & $84.84 \pm 0.02$ & $1.78 \pm 0.04$ & $96.68 \pm 0.01$ \\
72 & $0.27 \pm 0.10$ & $84.84 \pm 0.05$ & $1.17 \pm 0.06$ & $96.68 \pm 0.01$ \\
96 & $0.27 \pm 0.05$ & $84.84 \pm 0.06$ & $0.88 \pm 0.05$ & $96.68 \pm 0.10$ \\
\hline
\end{tabular}




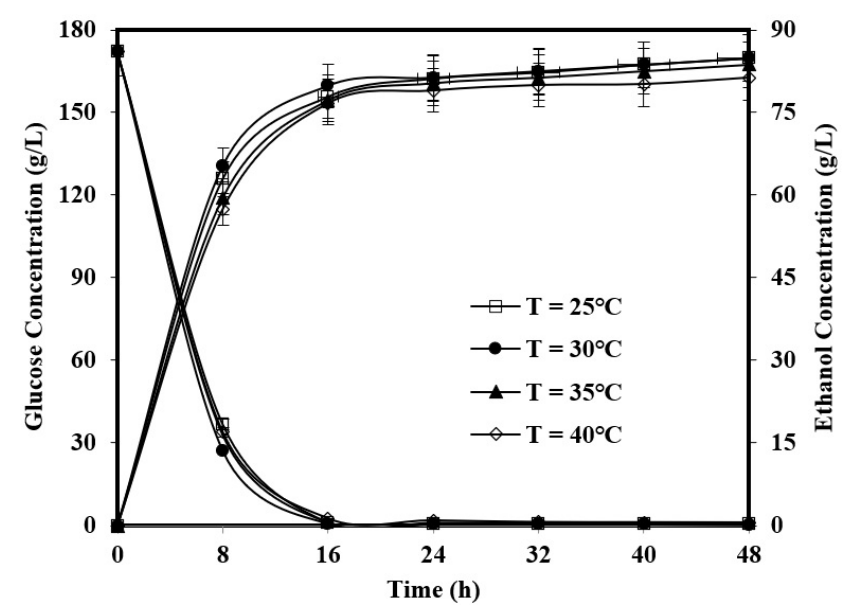

Fig. 1 Effect of temperature on ethanol and glucose concentrations during fermentation using immobilized yeast

stationary and death phases was found at $25{ }^{\circ} \mathrm{C}$ from the reduction of glucose concentration and the increase of ethanol concentration. It can also be observed that at temperatures of $30^{\circ} \mathrm{C}, 35^{\circ} \mathrm{C}$, and $40^{\circ} \mathrm{C}$ the glucose as the substrate was almost completely depleted at a shorter fermentation time (16 hours). Finally, this phenomenon may have reduced the fermentation rate, which leads to the occurrence of no further increase in ethanol concentration [53].

Fig. 1 shows that as the fermentation temperature further increases to beyond $30{ }^{\circ} \mathrm{C}$, the ethanol concentration produced decreases $[23,25]$. This is due to the tendency of disruption of $S$. cerevisiae cells activity causing the process of converting glucose into ethanol is inhibited as indicated by a slightly higher final glucose concentration [49]. Torija et al. [53] found a remarkable reduction of viable yeast cells at high temperatures, especially at $35^{\circ} \mathrm{C}$ and higher. In addition, the high fermentation temperature causes the reduction of the mechanical strength of the Na-alginate beads, which subsequently leads to the reduction of cell stability [23, 25].

At 48 hours fermentation time, glucose concentration decreased sharply from $172.00 \mathrm{~g} / \mathrm{L}$ to $0.54 \mathrm{~g} / \mathrm{L}$ and $0.27 \mathrm{~g} / \mathrm{L}$, respectively at temperature of $25^{\circ} \mathrm{C}$ and $30{ }^{\circ} \mathrm{C}$. Whereas at temperatures beyond $30^{\circ} \mathrm{C}$, higher final glucose concentrations were observed, i. e. $1.02 \mathrm{~g} / \mathrm{L}$ and $1.07 \mathrm{~g} / \mathrm{L}$ for fermentation at $35^{\circ} \mathrm{C}$ and $40^{\circ} \mathrm{C}$, respectively. It is supposed that at high temperatures a large number of yeast cells have died, causing a slower glucose conversion to ethanol. Fig. 1 also presents that ethanol concentration increased from $78.98 \mathrm{~g} / \mathrm{L}$ to $84.84 \mathrm{~g} / \mathrm{L}$ as the fermentation temperature increased from $25{ }^{\circ} \mathrm{C}$ to $30{ }^{\circ} \mathrm{C}$ suggesting that the $S$. cerevisiae yeast cells from instant dry yeast "Fermipan" is slightly thermoresistant. It is clearly shown in Fig. 1 that the highest ethanol concentration was achieved when fermentation was carried out at $30{ }^{\circ} \mathrm{C}$. Accordingly, some previous studies on fermentation of glucose using various strains of $S$. cerevisiae immobilized on Na-alginate beads and sweet sorghum stalks under acidic condition also reported that the optimum temperature exists at $30^{\circ} \mathrm{C}[17,25,26]$. However, ethanol concentration value declined from $84.84 \mathrm{~g} / \mathrm{L}$ to $81.33 \mathrm{~g} / \mathrm{L}$ as the fermentation temperature was further risen from $30{ }^{\circ} \mathrm{C}$ to $40{ }^{\circ} \mathrm{C}$. This is because the optimum temperature for the yeast cells to grow exists between $25^{\circ} \mathrm{C}$ to $30^{\circ} \mathrm{C}$ [17].

\subsubsection{Effect of pH on the ethanol production}

Because of fermentation processes needs active living yeast cells, variation in initial $\mathrm{pH}$ values should result in notable effects on ethanol yields and productivity. The effect of $\mathrm{pH}$ on ethanol production from glucose fermentation was studied at $30{ }^{\circ} \mathrm{C}$ using immobilized yeast loading of $0.50 \mathrm{~g}$ for 48 hours. The results of the study are presented in Fig. 2.

Immobilized $S$. cerevisiae yeast cells were active in the range of initial $\mathrm{pH}$ values of 3.0 to 6.0 and reached maximum ethanol productivity at a $\mathrm{pH}$ of 5.0. Fig. 2 demonstrates that at $\mathrm{pH} \mathrm{5}$, approximately $84 \%$ of the glucose has been consumed by yeast cells in just 16 hours. A previous study on glucose fermentation at $\mathrm{pH}$ of $4.5,5.0$, and 5.5 by Lee et al. [17] also revealed that $90 \%$ of the glucose had been converted to ethanol at $\mathrm{pH} 5$ in about 19.5 hours. Later, they concluded that the optimum $\mathrm{pH}$ for fermentation of glucose using $S$. cerevisiae immobilized on calcium alginate beads is at $\mathrm{pH}$ 5.0, which is in good agreement with the result of this study. Similarly, Narendranath and Power [22] also suggested that the optimum $\mathrm{pH}$ for glucose fermentation for ethanol preparation exists between 5.0 and 5.5.

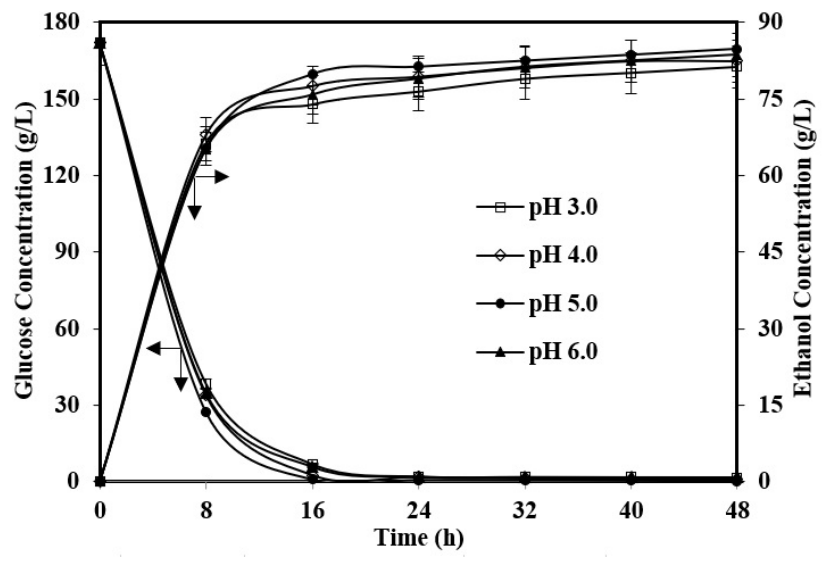

Fig. 2 Effect of $\mathrm{pH}$ on ethanol and glucose concentrations during fermentation using immobilized yeast 
In this study, the ethanol concentration produced at $\mathrm{pH}$ 5.0 as the optimum $\mathrm{pH}$ was $84.84 \mathrm{~g} / \mathrm{L}$ with a final glucose concentration of $0.27 \mathrm{~g} / \mathrm{L}$. It is necessary for the yeast to keep a fixed intracellular $\mathrm{pH}$ for optimum growth. There are various enzymes playing important roles inside the yeast cells throughout their growth and metabolism. Unfortunately, every enzyme requires an optimum $\mathrm{pH}$, which is acidic due to the acidophilic characteristic of the yeast itself. At lower $\mathrm{pH}$ values, the yeast cells have to provide more energy to either drive in or push out hydrogen ions in order to keep the optimum intracellular $\mathrm{pH}$. Therefore, if the extracellular $\mathrm{pH}$ is largely different from the optimum $\mathrm{pH}$ range, it becomes extremely hard for the cells to keep the intracellular $\mathrm{pH}$ to be constant, and causes the enzymes are not able to work customarily. Hence, if the enzymes undergo considerable deactivation, the yeast cells will be unable to grow and effectively convert glucose to ethanol [22]. Fermentation conditions at a $\mathrm{pH}$ below 5.0 can shorten the incubation time and this situation induces the production of acetic acid, whereas at $\mathrm{pH}$ beyond 5.0 causes ethanol production to decrease due to the formation of butyric acid [23]. The formation of acid in the fermentation media alters the permeability of some nutrients into the yeast cells [50], thus effectively hindering the growth of the yeast cells, and finally impacting the production of ethanol [35]. At a higher $\mathrm{pH}$ value ( $\mathrm{pH}$ 6.0), there is a smaller aberration between the internal and external $\mathrm{pH}$ values $(\Delta \mathrm{pH})$ as a result of the accumulation of undissociated acids inside the cell, which finally decreases the inhibition of yeast growth [22].

\subsubsection{Effect of immobilized yeast cell loading on the ethanol production}

The effect of immobilized yeast cell loading to determine the optimum conditions was studied at $30{ }^{\circ} \mathrm{C}$ and $\mathrm{pH} 5.0$ for 48 hours and the results are presented in Fig. 3. Fig. 3 shows that glucose consumption by yeast cells was very slow $(70 \%)$ at immobilized yeast cell loading of $0.25 \mathrm{~g}$. As the yeast mass increased up to $0.75 \mathrm{~g}$, the glucose consumption also increased and achieved a maximum value of $82 \%$. This result would suggest that virtually a high level of inoculum was obtained and all of the entrapped yeast cells actively took part in the fermentation [34, 54, 55].

However, a further increase in immobilized yeast cell loading to $1.0 \mathrm{~g}$ resulted in a reduction of glucose consumption (76\%). Ethanol induces inhibition of cell viability and growth and the fermentation rate. This situation further triggers the formation of acetic acid, which is reported to be

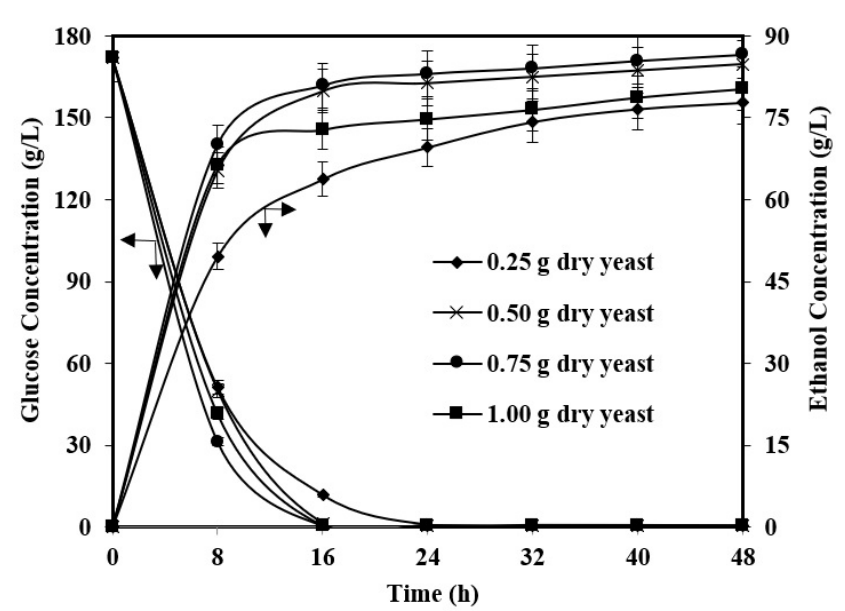

Fig. 3 Effect of immobilized yeast cell loading on ethanol and glucose concentrations during fermentation using immobilized yeast

strain - dependent [56]. Saccharomyces $s p$. is presumably unable to withstand a modest ethanol concentration [57]. Casey and Ingledew found that at an ethanol concentration of $20 \%$ (v/v) [58], the S. cerevisiae to perform fermentation is hindered, but yeast growth inhibition may happen at a much lower ethanol concentration [56]. Theoretically, ethanol must have impeded alcohol hydrogenase 1 and activated the alcohol hydrogenase 2 , which catalyzes the oxidation of ethanol to acetaldehyde and further oxidizes it to acetic acid by aldehyde dehydrogenase. Surprisingly, the use of larger immobilized yeast cell loading did not produce higher ethanol yield because the alleged conversion of glucose into ethanol is not optimal due to extremely rapid yeast cell growth on the Na-alginate beads [29].

An increase in yeast cell concentration within a certain range caused rapid glucose consumption, which leads to a significant increase in ethanol productivity [55]. As a result, the fermentation time becomes shorter as the yeast cells grow rapidly and directly consume glucose to produce ethanol [21]. This finding is in good agreement with a previous report that an increase in cell concentration of 3 to $6 \%$ was found to shorten the fermentation time from 72 hours to 48 hours [59].

\subsection{Evaluation of yeast cells growth on immobilized alginate beads}

To evaluate the growth of $S$. cerevisiae immobilized cell on Na-alginate beads, the outer surface of the fresh beads and beads after 48 hours of fermentation was observed with a magnification of $1000 \times$ and $2500 \times$ using SEM analysis as depicted in Figs. 4 and 5.

As seen in Fig. 4, the diameter of the Na-alginate beads slightly increased as result of the yeast growth inside 

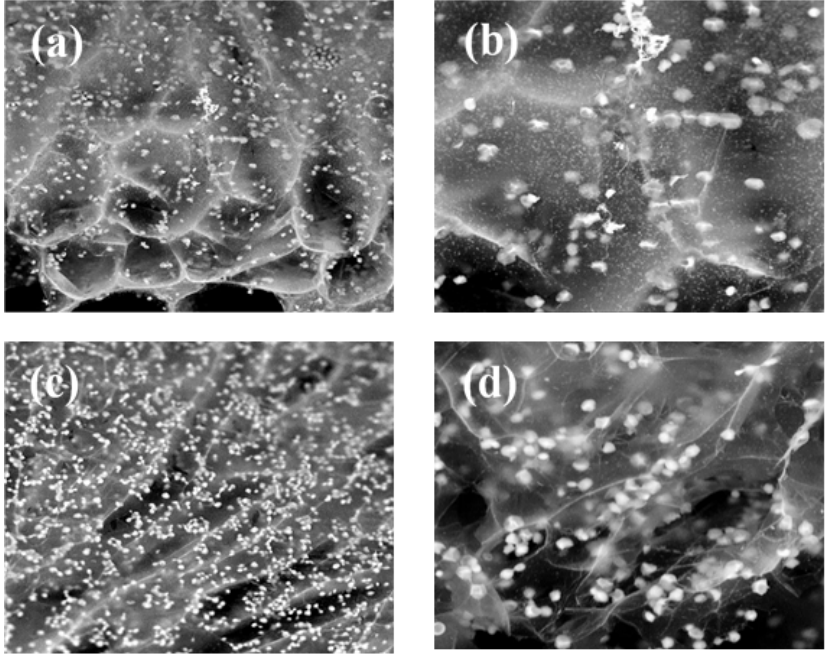

Fig. 4 Cross section of alginate beads in S. cerevisiae immobilization optimum conditions: (a) the outer surface of fresh beads is $1000 \times$ magnification (b) the outer surface of fresh beads is $2500 \times$ magnification (c) the outer surface of beads after 48 hours fermentation $1000 \times$ magnification (d) the outer surface of beads after 48 hours of fermentation at $2500 \times$ magnification
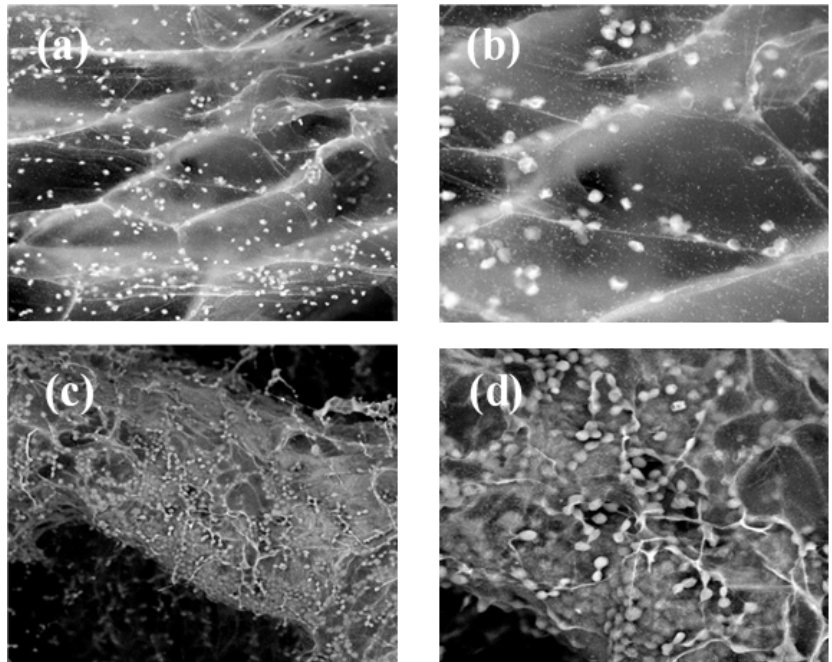

Fig. 5 Cross-section of alginate beads in S. cerevisiae immobilization optimum conditions: (a) the surface in fresh beads is $1000 \times$

magnification (b) the surface in fresh beads is $2500 \times$ magnification

(c) the inner surface of beads after 48 hours fermentation 1000

$\times$ magnification (d) the inner surface of beads after 48 hours of fermentation at $2500 \times$ magnification

the beads. The SEM images present that Na-alginate beads were densely covered with yeast cells both inside and on the external surface, reaching the maximum capacity of entrapped yeast cells. A similar observation was reported previously for immobilized $S$. cerevisiae yeast cells in hydroxyethylcellulose (HEC) gels [49].

Fig. 5 shows that $S$. cerevisiae cells in fresh beads grow and attach to the polymer walls of Na-alginate and have not formed any yeast cell colonies. After 48 hours of fermentation, the surface of the Na-alginate beads was covered by yeast cells in the form of new colonies. It was also observed that some yeast cells had come out from the surface of the Na-alginate beads, which was thought to be due to the rupture of the outer part of the Na-alginate polymer walls [49]. This finding was observed due to the high microbial load used and cell growth.

\subsection{Reusability of Saccharomyces cerevisiae immobilized on Na-alginate beads in successive fermentation cycles}

To investigate reusability, the $S$. cerevisiae immobilized on Na-alginate beads were reused in fermentation by employing the optimum conditions obtained for glucose fermentation to produce ethanol in the immobilized cell system. Fig. 6. presents the profile of ethanol concentration during the first and second fermentation cycles.

Fig. 6 demonstrates that the final ethanol concentration in the first and second fermentation cycle did not differ greatly, namely $86.56 \mathrm{~g} / \mathrm{L}$ and $88.13 \mathrm{~g} / \mathrm{L}$, respectively. The result is a good accordance with the previously published papers $[34,49,60]$. Surprisingly, ethanol concentrations in the second fermentation cycle were significantly higher than those in the first fermentation cycle as observed in the first, second and third hours, namely $24 \%$, $16 \%$, and $12.7 \%$ respectively. This phenomenon occurred because the lag phase time is shortened and the number of yeast cell inside Na-alginate beads is higher than that of the first fermentation cycle [34]. This is in accordance with several studies of reuse of alginate beads including being able to increase cell growth by up to $66 \%$ in hydrogen production on the $9^{\text {th }}$ day [38], increasing ethanol production from carrot waste using S. cerevisiae immobilized in Na-alginate beads by $10 \%$ [34] and ethanol production

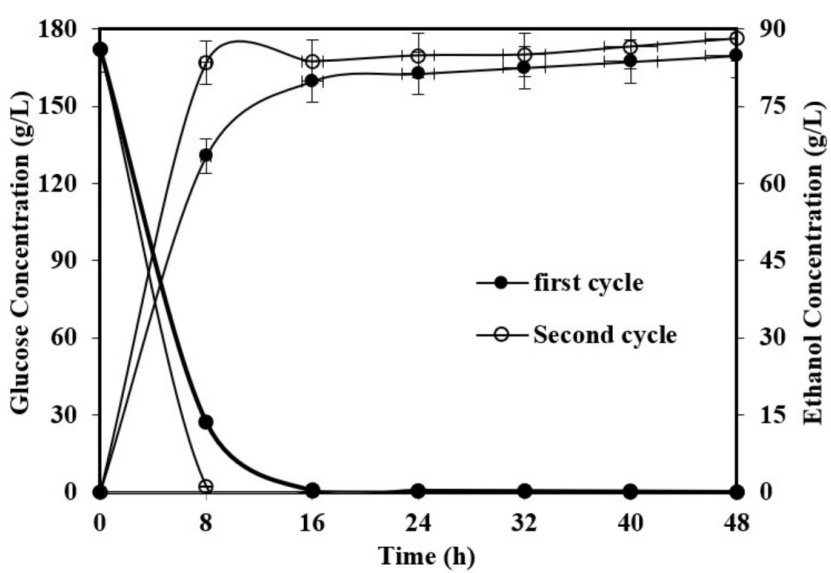

Fig. 6 Effect of fermentation cycle on the ethanol concentration 
from glucose using immobilized $S$. cerevisiae yeast cells in hydroxyethylcellulose (HEC) gels [49].

\subsection{Effect of using free and immobilized yeast cells}

Free cell glucose fermentation was conducted using the optimum conditions obtained from glucose fermentation with immobilized cells system investigated in this study, which used initial glucose concentration of $172.00 \mathrm{~g} / \mathrm{L}$ at $30^{\circ} \mathrm{C}, \mathrm{pH}$ 5.0 , immobilized yeast cell loading $0.75 \mathrm{~g}$ for 48 hours.

The ethanol concentration obtained from fermentation using immobilized cell system was $86.56 \mathrm{~g} / \mathrm{L}$ or approximately $17 \%$ greater than that of the free cell system $(74.00 \mathrm{~g} / \mathrm{L})$. The difference could be due to the fact that yeast cells are entrapped in Na-alginate beads, which are relatively protected from alterations of the environment condition [61]. Eiadpum et al. [8] also observed that a monoculture of $S$. cerevisiae immobilized on thin-shell silk cocoon was efficient for glucose fermentation, resulting in ethanol concentrations of $81.40 \mathrm{~g} / \mathrm{L}$ and $77.30 \mathrm{~g} / \mathrm{L}$ when using temperatures of $37{ }^{\circ} \mathrm{C}$ and $40^{\circ} \mathrm{C}$ and cane juice as substrate at an initial sugar concentration of $220 \mathrm{~g} / \mathrm{L}$. A similar result was reported by Nuanpeng et al. [27] who obtained about $2 \%$ higher ethanol concentration in an immobilized cell fermentation system than in fermentation using free cells. Whereas Behera et al. [60] found around $9 \%$ higher ethanol production from fermentation of glucose from Mahula flowers using an immobilization cell system than that of using a free cell system. This result is expected because Na-alginate beads used in the immobilized cell system functions as a barrier to cell release [31].

In general, the free cell systems are less tolerant to initial glucose concentrations and high ethanol concentration, which leads to a lower glucose conversion. From this view, the immobilized cell system is more robust and feasible fermentation technique than the free cell system because it shows higher ethanol productivity [29]. The immobilized cell system has been reported to be versatile in overcoming the disruption of nutrients by other

\section{References}

[1] Azhar, S. H. M., Abdulla, R. "Bioethanol production from galactose by immobilized wild-type Saccharomyces cerevisiae", Biocatalysis and Agricultural Biotechnology, 14, pp. 457-465, 2018.

https://doi.org/10.1016/j.bcab.2018.04.013

[2] Rastogi, M., Shrivastava, S. "Recent advances in second generation bioethanol production: An insight to pretreatment, saccharification and fermentation processes", Renewable and Sustainable Energy Reviews, 80, pp. 330-340, 2017.

https://doi.org/10.1016/j.rser.2017.05.225 microorganisms, environmental stress, extraneous toxins or poisons, and ultraviolet irradiation [62].

\section{Conclusion}

The combined autohydrolysis and organosolv pretreatments of OPEFB to produce cellulose and enzymatic hydrolysis of cellulose using cocktail enzymes (novozyme 188 and celluclast) have been satisfactorily performed to produce crude glucose with concentration of $172.00 \mathrm{~g} / \mathrm{L}$. Ethanol fermentation from crude glucose derived from oil palm empty fruit bunch with an initial concentration of $172.00 \mathrm{~g} / \mathrm{L}$ using Saccharomyces cerevisiae immobilized on Na-alginate beads has been successfully conducted to achieve higher ethanol yield, ethanol concentration and ethanol productivity than previously published similar works. The highest ethanol concentration and productivity obtained at 48 hours fermentation time were respectively $86.56 \mathrm{~g} / \mathrm{L}$ and $1.8 \mathrm{~g} / \mathrm{L} . \mathrm{h}$ leaving a final glucose concentration of $0.21 \mathrm{~g} / \mathrm{L}$. Fermentation time, temperature, $\mathrm{pH}$, immobilized yeast cell loading, and fermentation system are found to influence the ethanol productivity. The ethanol produced by fermentation using an immobilized cell system was $9 \%$ higher than that of the free cell system due to the fact that immobilization having the ability to support stable fermentation. The optimum conditions for ethanol production using fermentation with immobilized yeast cells system are at $30^{\circ} \mathrm{C}, \mathrm{pH} 5.0$, and immobilized yeast cell loading $0.75 \mathrm{~g}$ for 48 hours. The reusing of Na-alginate beads has been proven to result in a higher yield than fermentation using fresh beads. The ethanol concentration obtained from the second fermentation cycle was $88.13 \mathrm{~g} / \mathrm{L}$ with a productivity of $1.84 \mathrm{~g} / \mathrm{L} . \mathrm{h}$.

\section{Acknowledgement}

The authors exclusively gratefully acknowledge the Ministry of Research and Technology of the Republic of Indonesia for the financial support of this study through Hibah Pasca Doktor 2020 under contract No. 225-116/UN7.6.1/PP/2020.

[3] Pourbafrani, M., McKechnie, J., Maclean, H. L., Saville, B. A. "Life cycle greenhouse gas impacts of ethanol, biomethane and limonene production from citrus waste", Environmental Research Letters, 8(1), Article number: 015007, 2013. https://doi.org/10.1088/1748-9326/8/1/015007

[4] Kim, S., Kim, C. H. "Bioethanol production using the sequential acid/alkali-pretreated empty palm fruit bunch fiber", Renewable Energy, 54, pp. 150-155, 2013.

https://doi.org/10.1016/j.renene.2012.08.032 
[5] Khan, Z., Dwivedi, A. K. "Fermentation of Biomass for Production of Ethanol: A Review", Universal Journal of Environmental Research and Technology, 3(1), pp. 1-13, 2013. [online] Available at: http://www.environmentaljournal.org/volume-3-issue-1.shtml [Accessed: 12 June 2020]

[6] Gökgöz, M., Yiğitoğlu, M. "High productivity bioethanol fermentation by immobilized Saccharomyces bayanus onto carboxymethylcellulose-g- poly (Nvinyl-2-pyrrolidone) Beads", Artificial Cells, Nanomedicine, and Biotechnology, 41(2), pp. 137-143, 2013. https://doi.org/10.3109/10731199.2012.696069

[7] Sakurai, A., Nishida, Y., Saito, H., Sakakibara, M. "Ethanol production by repeated batch culture using yeast cells immobilized within porous cellulose carriers", Journal of Bioscience and Bioengineering, 90 (5), pp. 526-529, 2000. https://doi.org/10.1016/S1389-1723(01)80034-7

[8] Eiadpum, A., Limtong, S., Phisalaphong, M. "High-temperature ethanol fermentation by immobilized coculture of Kluyveromyces marxianus and Saccharomyces cerevisiae", Journal of Bioscience and Bioengineering, 114(3), pp. 325-329, 2012.

https://doi.org/10.1016/j.jbiosc.2012.04.004

[9] Hamzah, F., Idris, A., Shuan, T. K. "Preliminary study on enzymatic hydrolysis of treated oil palm (Elaeis) empty fruit bunches fibre (EFB) by using combination of cellulase and $\beta 1$ - 4 glucosidase", Biomass and Bioenergy, 35(3), pp. 1055-1059, 2011.

https://doi.org/10.1016/j.biombioe.2010.11.020

[10] Shamsudin, S., Shah, U. K. M., Zainudin, H., Abd-Aziz, S., Kamal, S. M. M., Shirai, Y., Hassan, M. A. "Effect of steam pretreatment on oil palm empty fruit bunch for the production of sugars", Biomass and Bioenergy, 36, pp. 280-288, 2012.

https://doi.org/10.1016/j.biombioe.2011.10.040

[11] Waluyo, J., Burhani, D., Hikmah, N., Sudiyani, Y. "Immobilization of Saccharomyces cerevisiae using Ca-alginate for bioethanol production from empty fruit bunch of oil palm", AIP Conference Proceedings, 1803(1), Article number: 020016, 2017. https://doi.org/10.1063/1.4973143

[12] Sugiharto, Y. E. C., Harimawan, A., Kresnowati, M. T. A. P., Purwadi, R. Mariyana, R., Andry, Fitriana, H. N., Hosen H. F. "Enzyme feeding strategies for better fed-batch enzymatic hydrolysis of empty fruit bunch", Bioresource Technology, 207, pp. 175-179, 2016. https://doi.org/10.1016/j.biortech.2016.01.113

[13] Chin, S. X., Chia, C. H., Zakaria, S. "Production of Reducing Sugar from Oil Palm Empty Fruit Bunch (EFB) Cellulose Fibres via Acid Hydrolysis", BioResources, 8(1), pp. 447-460, 2013. https://doi.org/10.15376/biores.8.1.447-460

[14] Sumathi, S., Chai, S. P., Mohamed, A. R. "Utilization of oil palm as a source of renewable energy in Malaysia", Renewable and Sustainable Energy Reviews, 12(9), pp. 2404-2421, 2008. https://doi.org/10.1016/j.rser.2007.06.006

[15] Loh, S. K, Choo, Y. M. "Prospect, Challenges and Opportunities on Biofuels in Malaysia", In: Pogaku, R., Sarbatly, R. (eds.) Advances in Biofuels, Springer, Boston, MA, USA, pp. 3-14, 2013. https://doi.org/10.1007/978-1-4614-6249-1_1
[16] Cui, X., Zhao, X., Zeng, J., Loh, S. K., Choo, Y. M., Liu, D. "Robust enzymatic hydrolysis of Formiline-pretreated oil palm empty fruit bunches (EFB) for efficient conversion of polysaccharide to sugars and ethanol", Bioresource Technology, 166, pp. 584-591, 2014. https://doi.org/10.1016/j.biortech.2014.05.102

[17] Lee, K. H., Choi, I. S., Kim, Y.-G., Yang, D.-J. Bae, H.-J. "Enhanced production of bioethanol and ultrastructural characteristics of reused Saccharomyces cerevisiae immobilized calcium alginate beads", Bioresource Technology, 102(17), pp. 8191-8198, 2011. https://doi.org/10.1016/j.biortech.2011.06.063

[18] Phisalaphong, M., Srirattana, N., Tanthapanichakoon, W. "Mathematical modeling to investigate temperature effect on kinetic parameters of ethanol fermentation", Biochemical Engineering Journal, 28(1), pp. 36-43, 2006. https://doi.org/10.1016/j.bej.2005.08.039

[19] Ortiz-Muñiz, B., Carvajal-Zarrabal, O., Torrestiana-Sanchez, B., Aguilar-Uscanga, M. G. "Kinetic study on ethanol production using Saccharomyces cerevisiae ITV-01 yeast isolated from sugar cane molasses", Journal of Chemical Technology and Biotechnology., 85(10), pp. 1361-1367, 2010. https://doi.org/10.1002/jctb.2441

[20] Tesfaw, A., Assefa, F. "Current Trends in Bioethanol Production by Saccharomyces cerevisiae: Substrate, Inhibitor Reduction, Growth Variables, Coculture, and Immobilization", International Scholarly Research Notices, 2014, Article ID: 532852, 2014. https://doi.org/10.1155/2014/532852

[21] Azhar, S. H. M., Abdulla, R., Jambo, S. A. Marbawi, H., Gansau, J. A., Faik, A. A. M., Rodrigues, K. F. "Yeast in sustainable bioethanol production: A review", Biochemistry and Biophysics Reports, 10, pp. 52-61, 2017. https://doi.org/10.1016/j.bbrep.2017.03.003

[22] Narendranath, N. V., Power, R. "Relationship between $\mathrm{pH}$ and Medium Dissolved Solids in Terms of Growth and Metabolism of Lactobacilli and Saccharomyces cerevisiae during Ethanol Production", Applied and Environmental Microbiology, 71(5), pp. 2239-2243, 2005.

https://doi.org/10.1128/AEM.71.5.2239-2243.2005

[23] Lin, Y., Zhang, W., Li, C., Sakakibara, K., Tanaka, S., Kong, H. "Factors affecting ethanol fermentation using Saccharomyces cerevisiae BY4742", Biomass and Bioenergy, 47, pp. 395-401, 2012. https://doi.org/10.1016/j.biombioe.2012.09.019

[24] Yuangsaard, N., Yongmanitchai, W., Yamada, M., Limtong, S. "Selection and characterization of a newly isolated thermotolerant Pichia Kudriavzevii strain for ethanol production at high temperature from cassava starch hydrolysate", Antonie van Leeuwenhoek 103(3), pp. 577-588, 2013. https://doi.org/10.1007/s10482-012-9842-8

[25] Mishra, A., Sharma, A. K., Sharma, S., Bagai, R., Mathur, A. S., Gupta, R. P., Tuli, D. K. "Lignocellulosic ethanol production employing immobilized Saccharomyces cerevisiae in packed bed reactor", Renewable Energy, 98, pp. 57-63, 2016. https://doi.org/10.1016/j.renene.2016.02.010

[26] Ariyajaroenwong, P., Laopaiboon, P., Jaisil, P., Laopaiboon, L. "Repeated-Batch Ethanol Production from Sweet Sorghum Juice by Saccharomyces cerevisiae Immobilized on Sweet Sorghum Stalks", Energies, 5(4), pp. 1215-1225, 2012. https://doi.org/10.3390/en5041215 
[27] Nuanpeng, S., Thanonkeo, S., Klanrit, P., Thanonkeo, P. "Ethanol production from sweet sorghum by Saccharomyces cerevisiae DBKKUY-53 immobilized on alginate-loofah matrices", Brazilian Journal of Microbiology, 49, pp. 140-150, 2018.

https://doi.org/10.1016/j.bjm.2017.12.011

[28] Santos, E. L. I., Rostro-Alanís, M., Parra-Saldívar, R., Alvarez, A. J. "A novel method for bioethanol production using immobilized yeast cells in calcium-alginate films and hybrid composite pervaporation membrane", Bioresource Technology, 247, pp. 165-173, 2018. https://doi.org/10.1016/j.biortech.2017.09.091

[29] Nikolić, S., Mojović, L., Pejin, D., Rakin, M., Vukašinović, M. "Production of bioethanol from corn meal hydrolyzates by free and immobilized cells of Saccharomyces cerevisiae var. ellipsoideus", Biomass and Bioenergy, 34 (10), pp. 1449-1456, 2010. https://doi.org/10.1016/j.biombioe.2010.04.008

[30] Smidsrød, O., Skja k-Br1k, G. "Alginate as immobilization matrix for cells", Trends in Biotechnology, 8, pp. 71-78, 1990. https://doi.org/10.1016/0167-7799(90)90139-O

[31] Duarte, J. C., Rodrigues, J. A. R., Moran, P. J. S., Valença, G. P., Nunhez, J. R. "Effect of immobilized cells in calcium alginate beads in alcoholic fermentation", AMB Express, 3(1), Article number: 31, 2013.

https://doi.org/10.1186/2191-0855-3-31

[32] Ballesteros, M., Oliva, J. M., Negro, M. J., Manzanares, P., Ballesteros, I. "Ethanol from lignocellulosic materials by a simultaneous saccharification and fermentation process (SFS) with Kluyveromyces marxianus CECT 10875", Process Biochemistry, 39(12), pp. 1843-1848, 2004.

https://doi.org/10.1016/j.procbio.2003.09.011

[33] Rakin, M.. Mojovic, L., Nikolic, S., Vukasinovic, M., Nedovic, V. "Bioethanol production by immobilized Sacharomyces cerevisiae var. ellipsoideus Cells", African Journal of Biotechnology, 8(3), pp. 464-471, 2009. [online] Available at: https://academicjournals.org/journal/AJB/article-abstract/2C631D45646 [Accessed: 30 June 2020]

[34] Clementz, A. L., Aimaretti, N. R., Manuale, D., Codevilla, A., Yori, J. C. "Optimization of ethanol fermentation from discarded carrots using immobilized Saccharomyces cerevisiae", International Journal of Energy and Environmental Engineering, 6(2), pp. 129-135, 2015.

https://doi.org/10.1007/s40095-014-0157-6

[35] Zhang, C.-M., Jiang, L., Mao, Z.-G., Zhang, J.-H., Tang, L. "Effects of Propionic Acid and $\mathrm{pH}$ on Ethanol Fermentation by Saccharomyces cerevisiae in Cassava Mash", Applied Biochemistry and Biotechnology., 165, pp. 883-891, 2011. https://doi.org/10.1007/s12010-011-9305-0

[36] Pasma, S. A., Daik, R., Maskat, M. Y. "Production of succinic acid from oil palm empty fruit bunch cellulose using Actinobacillus succinogenes", AIP Conference Proceedings, 1571(1), pp. 753-759, 2013.

https://doi.org/10.1063/1.4858745

[37] Laopaiboon, L., Laopaiboon,P. "Ethanol production from sweet sorghum juice in repeated-batch fermentation by Saccharomyces cerevisiae immobilized on corncob", World Journal of Microbiology and Biotechnology, 28(2), pp. 559-566, 2012. https://doi.org/10.1007/s11274-011-0848-6
[38] Damayanti, A., Sarto, S., Sediawan, W. B. "Biohydrogen Production by Reusing Immobilized Mixed Culture in Batch System", International Journal of Renewable Energy Development, 9(1), pp. 37-42, 2020. https://doi.org/10.14710/ijred.9.1.37-42

[39] Inal, M., Yiğitoğlu, M. "Production of bioethanol by immobilized Saccharomyces cerevisiae onto modified sodium alginate gel", Journal of Chemical Technology and Biotechnology, 86(12), pp. 1548-1554, 2011. https://doi.org/10.1002/jctb.2678

[40] Hage, R. E., Chrusciel, L., Desharnais, L., Brosse, N. "Effect of autohydrolysis of Miscanthus $x$ giganteus on lignin structure and organosolv delignification”, Bioresource Technology, 101(23), pp. 9321-9329, 2010. https://doi.org/10.1016/j.biortech.2010.06.143

[41] Yeh, A.-I., Huang, Y.-C., Chen, S. H. "Effect of particle size on the rate of enzymatic hydrolysis of cellulose", Carbohydrate Polymers, 79(1), pp. 192-199, 2010.

https://doi.org/10.1016/j.carbpol.2009.07.049

[42] Marais, J. P., de Wit, J. L., Quicke, G. V. "A critical examination of the Nelson-Somogyi method for the determination of reducing sugars", Analytical Biochemistry, 15(3), pp. 373-381, 1966. https://doi.org/10.1016/0003-2697(66)90098-4

[43] Somogyi, M. "A new reagent for the determination of sugars", The Journal of Biological Chemistry, 160(1), pp. 61-68, 1945. https://doi.org/10.1016/S0021-9258(18)43097-9

[44] Sriariyanun, M., Mutrakulcharoen, P., Tepaamorndech, S., Cheenkachorn, K., Rattanaporn, K. "A Rapid Spectrophotometric Method for Quantitative Determination of Ethanol in Fermentation Products", Oriental Journal of Chemistry, 35(2), pp. 744-750, 2019. https://doi.org/10.13005/ojc/350234

[45] Macleod, L. D. "Determination of alcohol by microdiffusion", The Journal of Biological Chemistry, 181(1), pp. 323-331, 1949. https://doi.org/10.1016/s0021-9258(18)56652-7

[46] da Silva, R. O., Batistote, M, Cereda, M. P. "Alcoholic fermentation by wild yeasts under thermal, osmotic and ethanol stress", Brazilian Archives of Biology and Technology, 56(2), pp. 161-169, 2013. http://doi.org/10.1590/S1516-89132013000200001

[47] Norton, S., D’Amore, T., "Physiological effects of yeast cell immobilization: Applications for brewing", Enzyme and Microbial Technology, 16(5), pp. 365-375, 1994. http://doi.org/10.1016/0141-0229(94)90150-3

[48] Montealegre, C. M., Dionisio, E. R., Sumera, L. V., Adolacion, J. R. T., De Leon, R. L. "A Comparison between the Performance of S. cerevisiae Cells Immobilized in Nata de Coco Biocellulose and Calcium Alginate during Continuous Bioethanol Production", International Journal of Chemical Engineering and Applications, 3(4), pp. 237-242, 2012. https://doi.org/10.7763/IJCEA.2012.V3.193 h

[49] Winkelhausen, E. Velickova, E., Amartey, S. A., Kuzmanova, S. "Ethanol Production Using Immobilized Saccharomyces cerevisiae in Lyophilized Cellulose Gel", Applied Biochemistry and Biotechnology, 162, pp. 2214-2220, 2010. https://doi.org/10.1007/s12010-010-8995-z 
[50] Amekan, Y., Guntoro "Bioethanol production using alginate from Sargassum binderi as an immobilization matrix for Saccharomyces cerevisiae D. 01 cells in a batch reactor with circulation", Research Journal of Pharmaceutical, Biological and Chemical Sciences, 8(2), pp. 1925-1933, 2017. [online] Available at: https://www. researchgate.net/publication/319809275_Bioethanol_Production Using_Alginate_from_Sargassum_binderi_as_an_Immobilization Matrix_for_Saccharomyces_cerevisiae_D01_cells_in_a_Batch Reactor_with_Circulation [Accessed: 30 June 2020]

[51] Borovikova, D., Scherbaka, R., Patmalnieks, A. Rapoport, A. "Effects of yeast immobilization on bioethanol production", Biotechnology and Applied Biochemistry, 61(1), pp. 33-39, 2014. https://doi.org/10.1002/bab.1158

[52] Zhang, Q., Wu, D., Lin, Y., Wang, X., Kong, H., Tanaka, S. "Substrate and Product Inhibition on Yeast Performance in Ethanol Fermentation", Energy Fuels, 29(2), pp. 1019-1027, 2015. https://doi.org/10.1021/ef502349v

[53] Torija, M. J., Rozès, N., Poblet, M., Guillamón, J. M., Mas, A. "Effects of fermentation temperature on the strain population of Saccharomyces cerevisiae", International Journal of Food Microbiology, 80(1), pp. 47-53, 2003. https://doi.org/10.1016/S0168-1605(02)00144-7

[54] de Assis Castro, R. C., Roberto, I. C. "Effect of nutrient supplementation on ethanol production in different strategies of saccharification and fermentation from acid pretreated rice straw", Biomass and Bioenergy, 78, pp. 156-163, 2015 https://doi.org/10.1016/j.biombioe.2015.04.019

[55] Zabed, H., Faruq, G., Sahu, J. N., Azirun, M. S., Hashim, R., Boyce, A. N. "Bioethanol Production from Fermentable Sugar Juice", The Scientific World Journal, Article ID 957102, 2014. https://doi.org/10.1155/2014/957102

[56] Amadi, P. U., Ifenacho, M. O. "Impact of changes in fermentation time, volume of yeast, and mass of plantain pseudo-stem substrate on the simultaneous saccharification and fermentation potentials of African land snail digestive juice and yeast", Journal of Genetic Engineering and Biotechnology, 14(2), pp. 289-297, 2016. https://doi.org/10.1016/j.jgeb.2016.09.002
[57] Borthwick, R., Stewart, G. G., Rees, E. M. R., Jones, H. L., Hodgson, J. A. "Very high gravity fermentations with ale and lager yeast strains", In: Proceeding of The 26th European Brewery Convention Congress, Oxford, UK, 1997, pp. 493-500.

[58] Casey, G. P., Chen, E. C.-H., Ingledew, W. M. "High-Gravity Brewing: Production of High Levels of Ethanol without Excessive Concentration of Esters and Fusel Alcohols", Journal of the American Society of Brewing Chemists, 43(4), pp. 179-182, 1985. https://doi.org/10.1094/ASBCJ-43-0179

[59] Breisha, G. Z. "Production of 16\% ethanol from 35\% sucrose", Biomass and Bioenergy, 34(8), pp. 1243-1249, 2010. https://doi.org/10.1016/j.biombioe.2010.03.017

[60] Behera, S., Mohanty, R. C., Ray, R. C. "Ethanol production from Mahua (Madhuca latifolia L.) flowers with immobilized cells of Saccharomyces cerevisiae in Luffa cylindrica L. sponge discs", Applied Energy, 88(1), pp. 212-215, 2011. https://doi.org/10.1016/j.apenergy.2010.07.035

[61] Buzas, Z., Dallmann, K., Szajani, B. "Influence of pH on the growth and ethanol production of free and immobilized Saccharomyces cerevisiae cells", Biotechnology and Bioengineering, 34(6), pp. 882-884, 1989. https://doi.org/10.1002/bit.260340620

[62] Covarrubias, S. A., De-Bashan, L. E., Moreno, M., Bashan, Y "Alginate beads provide a beneficial physical barrier against native microorganisms in wastewater treated with immobilized bacteria and microalgae", Applied Microbiology and Biotechnology, 93(6), pp. 2669-2680, 2012.

https://doi.org/10.1007/s00253-011-3585-8 